\title{
ФТОРПОЛИМЕРНЫЕ КОМПОЗИЦИОННЫЕ МАТЕРИАЛЫ И ЗАЩИТНЫЕ ПОКРЫТИЯ ДЛЯ ЭКСТРЕМАЛЬНЫХ УСЛОВИЙ АРКТИЧЕСКОЙ ЗОНЫ
}

\author{
Д.П. Кирюхин, Г.А. Кичигина, П. П. Кущ \\ ДМИТРИЙ ПАВЛОВИЧ КИРЮХИН - д.х.н., заведующий лабораторией Института проблем химической \\ физики РАН. Специалист в области радиационной химии, криохимии, синтеза и использования фторполи- \\ меров.E-mail:kir@icp.ac.ru.
}

ГАЛИНА АНАТОЛЬЕВНА КИЧИГИНА - к.х.н., старший научный сотрудник Института проблем химической физики РАН. Специалист в области радиационной химии, криохимии. E-mail: kga@icp.ac.ru.

ПАВЕЛ ПРОКОФЬЕВИЧ КУЩ - к.х.н., старший научный сотрудник Института проблем химической физики РАН. Специалист в области радиационной химии, теломеров. E-таil: kpp@icp.ac.ru.

142432, г. Черноголовка, Московской обл., проспект академика Семенова, д. 1. Институт проблем химической физики РАН.

Рассмотрены особенности использования радиационно-синтезированных теломеров тетрафторэтилена для создания новых фторполимерных композиционных материалов и защитных покрытий в экстремальных климатических условиях Арктики. Основное внимание уделено использованию теломеров для гидрофобизации высокопористых теплозащитных, теплоизоляционных материалов на основе квариевых волокон марок ТКВ (тонкое квариевое волокно) и ТЗМК-10 и стеклотканей.

Ключевые слова: теломеры, тетрафторэтилен, гидрофобизация, кварцевые волокна, стеклоткань.

\section{FLUOROPOLYMER COMPOSITE MATERIALS AND PROTECTIVE COATINGS FOR THE EXTREME CONDITIONS OF THE ARCTIC ZONE}

\author{
D. P. Kiryukhin, G.A. Kichigina, P.P. Kushch
}

1 Akademika Semenova Avenue, Chernogolovka, Moscow region, 142432, Russia. Institute of problems of chemical physics of the Russian Academy of Sciences

The features of using radiation-synthesized tetrafluoroethylene telomers to create new fluoropolymer composite materials and protective coatings in the extreme climatic conditions of the Arctic are considered. The main attention is paid to the use of telomeres for hydrophobization of highly porous heat-shielding, heat-insulating materials based on quartz fibers of the TKV (thin quartz fiber), TZMK-10 brands and fiberglass

Keywords: telomeres, tetrafluoroethylene, hydrophobization, quartz fibers, fiberglass. 


\section{Введение}

Фторполимеры, в частности, политетрафторэтилен (фторопласт-4, тефлон, ПТФЭ), композиционные материалы и покрытия на его основе, в наибольшей степени отвечают требованиям, предъявляемым к арктическим материалам в экстремально жестких режимах эксплуатации. ПТФЭ, помимо комплекса уникальных свойств, обладает способностью сохранять их в широком интервале температур $\left(-60{ }^{\circ} \mathrm{C}-+60{ }^{\circ} \mathrm{C}\right)$, давлений, влажности $(90 \%)$. Недостатком фторопласта-4 является относительно низкая износостойкость, ограничивающая ресурс его работы. Одним из подходов к повышению износостойкости ПТФЭ является синтез композиций на его основе, наполненных порошками и волокнами разного состава и количества. Вторым существенным недостатком ПТФЭ является его нерастворимость, обусловленная высокой молекулярной массой, которая усложняет технологию создания фторполимерных защитных покрытий. Альтернативой ПТФЭ являются радиационно-синтезированные низкомолекулярные полимеры (теломеры) ТФЭ [1-7]. В качестве источника ионизирующего излучения использовано $\gamma$-излучение Со-60 уникальной научной установки (УНУ «Гамматок-100» ИПХФ РАН) [8]. Радиационно-химический синтез в различных растворителях позволяет получать теломеры ТФЭ с разной длиной цепи и активными функциональными концевыми группами, которые обеспечивают связь молекулы теломера с подложкой. Для их синтеза сконструирован специальный реактор, позволяющий нарабатывать необходимое для экспериментов количество концентрированных растворов теломеров. Синтезированные теломеры ТФЭ были использованы для создания новых фторполимерных композиционных материалов (стеклополимерные композиционные материалы с использованием кремнеземной, алюмоборосиликатной, карамелизованной стеклотканей, гидрофобные высокопористые керамические материалы на основе оксидных и углеродных волокон, функциональные композиты на основе нанодисперсных частиц и др.), термостойких сверхгидрофобных и антифрикционных защитных покрытий на различные материалы (текстильные, природные целлюлозосодержащие композиционные материалы, дерево, металл и металлические славы, компоненты энергетических композитов и т.д.) [9-23]. Предложенные технологии не имеют пока аналогов в мировой практике и защищены рядом патентов [2, 24-29].

В данной работе рассмотрены два направления использования теломеров ТФЭ - получение гидрофобных покрытий стекло- и кремнеземных тканей и гидрофобизация высокопористых теплозащитных, теплоизоляционных материалов на основе кварцевых волокон. Эти материалы имеют низкую удельную плотность и теплопроводность, могут длительно эксплуатироваться при температуре до $1200{ }^{\circ} \mathrm{C}$, поэтому широко востребованы в различных отраслях промышленности, включая транспортные и спасательные средства, предназначенные для работ в Арктике. Основным их недостатком является гидрофильность, обусловленная химическим составом волокон и высокоразвитой пористой структурой. Краевой угол смачивания поверхностей оксидов кремния близок к нулю, что приводит к интенсивному впитыванию влаги в значительных количествах (600-700\% по массе) при погружении в воду. Присутствие воды в межволоконном пространстве материалов, в частности марок ТКВ (тонкое кварцевое волокно) и ТЗМК-10 аннулирует их высокие тепло-, звукоизоляционные и эксплуатационные свойства, а при низких температурах приводит к их разрушению, поэтому гидрофобизация таких материалов весьма актуальна [31-33].

В качестве гидрофобизаторов использованы растворы радиационно-синтезированных теломеров ТФЭ, полученных в ряде растворителей, имеющих разную длину цепи и различные концевые группы, которые оказывают влияние на свойства теломеров.

\section{Радиационно-химический синтез теломеров тетрафторэтилена}

В результате радиационного синтеза образуются теломеры ТФЭ, имеющие общую структурную формулу $\mathrm{R}_{1}-\left(\mathrm{CF}_{2}-\mathrm{CF}_{2}\right)_{\mathrm{n}} \mathrm{R}_{2}$, где $\mathrm{n}-$ количество звеньев ТФЭ в теломере, $\mathrm{R}_{1}, \mathrm{R}_{2}$ - фрагменты молекулы растворителя, в котором проводился синтез. Свойства теломеров (растворимость, термостабильность, адгезия и др.) зависят от длины цепи $\mathrm{n}$ и, что немаловажно, от природы концевых групп, которые могут быть химически активными. Исходя из этого, для дальнейшего использования был синтезирован ряд теломеров. Синтез проводился либо в специально сконструированном реактоpe [11], либо в стеклянных ампулах по стандартной методике $[12,13]$. Подбор растворителей проводился в двух направлениях. С одной стороны, были получены теломеры, имеющие различную длину цепи (n 10-100), что позволило сделать выводы об оптимальном значении $\mathbf{n}$ для получения гидрофобных покрытий. В качестве растворителей были использованы ацетон, $\left(\mathrm{C}_{3} \mathrm{H}_{6} \mathrm{O}\right)$, этилацетат $\left(\mathrm{C}_{4} \mathrm{H}_{8} \mathrm{O}_{2}\right.$, ЭА), хлористый бутил $\left(\mathrm{C}_{4} \mathrm{H}_{9} \mathrm{Cl}\right.$, ХБ), пентафтор- 
хлорбензол $\left(\mathrm{C}_{6} \mathrm{~F}_{5} \mathrm{Cl}\right.$, ПФХБ), трифтортрихлорэтан $\left(\mathrm{C}_{2} \mathrm{~F}_{3} \mathrm{Cl}_{3}\right.$, фреон113).

Молекулярная структура всех полученных теломеров была изучена методом ИК-спектроскопии. В ИК-спектрах теломеров, наряду с наиболее интенсивными полосами поглощения в области 1152 и $1208 \mathrm{~cm}^{-1}$ (валентные колебания связи C-F тетрафторэтиленовой цепи) наблюдается ряд полос, которые регистрируются в областях поглощения соответствующих растворителей. Эти полосы связанны с наличием концевых групп и свидетельствуют о вхождении фрагментов молекулы растворителя в состав теломера $[5,6,12,13]$. Теломеры, полученные в ХБ, ПФХБ и фреоне 113 были проанализированы методом элементного анализа на содержание хлора. Средняя длина цепи рассчитывалась по содержанию хлора в теломере в предположении, что концевые группы теломера в сумме дают молекулу растворителя, в котором проводился синтез. Средняя длина цепи теломеров в ХБ составляет 10-15 звеньев ТФЭ, а в ПФХБ и во фреоне $113 \sim 50$ и 100 звеньев, соответственно. Эти результаты хорошо согласуются с данными термогравиметрии (рис. 1.)

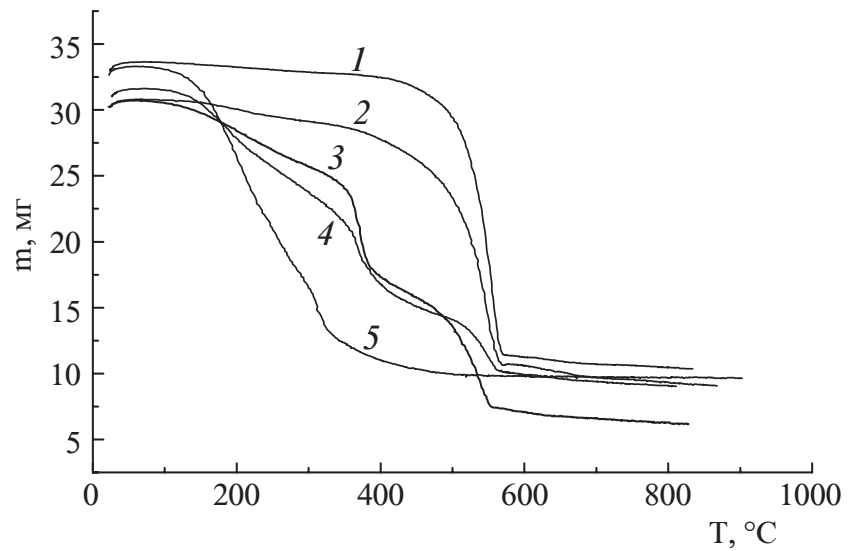

Рис. 1. Термогравиметрические кривые теломеров во фреоне 113 (1), ПФХБ (2), ацетоне (3), ХБ (4) $u$ ЭA (5)

Очевидно, что наиболее термостабильными являются длинноцепочечные теломеры ТФЭ во фреоне 113 и ПФХБ, а менее термостабильны теломеры в ЭА. Температура, при которой происходит потеря 50 \% массы образцов теломеров во фреоне 113 и ПФХБ составляет $\sim 530-550{ }^{\circ} \mathrm{C}$. Теломеры в ацетоне теряют $50 \%$ массы при нагреве до $350{ }^{\circ} \mathrm{C}$, а теломеры в ХБ и ЭА при температуpe менее $300{ }^{\circ} \mathrm{C}$. Эти результаты необходимо учитывать при дальнейшем выборе теломера для создания гидрофобных покрытий различных материалов, поскольку термостабильность теломеров определяет температурный интервал, в котором могут применяться модифицированные материалы без потери качества покрытия.

Другим важным параметром, определяющим свойства теломеров, является химическая активность концевых групп $\left(\mathrm{R}_{1}, \mathrm{R}_{2}\right)$. Концевые группы теломеров, в частности, описанных выше, являются химически малоактивными, а при создании композиционных материалов и покрытий желательно химическое присоединение молекул теломера к матрице. В связи с этим возникает необходимость получения теломеров с химически активными функциональными группами, в частности, гидроксильными, силановыми и аминогруппами. Исходя из этого, были синтезированы теломеры с ОН- и $\mathrm{NH}_{2}$-группами. Синтез их более сложен, он проводился в бинарных растворителях фреон 113 + аммиак и фреон 113 + этанол [33]. Во фреоне 113 процесс протекает очень эффективно, в результате образуются теломеры с большой длиной цепи, что не всегда позволяет получить качественное гидрофобное покрытие. Аммиак и этанол, добавленные в состав растворителя, выполняют роль дополнительных передатчиков цепи и позволяют получить более короткоцепочечные теломеры, имеющие в составе, по крайней мере, одну концевую ОН- или $\mathrm{NH}_{2}$-группу. Важен также тот факт, что длину цепи теломеров можно регулировать, изменяя концентрацию аммиака или этанола в смеси растворителей. Это подтверждается результатами элементного анализа и изучением ИКспектров. Отметим также, что получить теломеры с указанными концевыми группами, проводя синтез в этаноле или аминах, практически невозможно, поскольку образуются теломеры с длиной цепи 2-3 звена, которые не пригодны для получения покрытий или композитов.

О наличии активных концевых групп в составе теломеров свидетельствуют ИК-спектры (рис. 2) и результаты элементного анализа на содержание хлора и азота.

Изучение спектров ИК-поглощения позволяет получить информацию не только о молекулярной структуре теломеров, но и сделать качественные выводы о длине цепи продукта, оценив относительную интенсивность полос поглощения концевых групп и полос колебаний связей C-F тетрафторэтиленовой цепи. На рис.2 приведены спектры теломеров, полученных в чистом фреоне и смесях телогенов с различным содержанием аммиака и спирта. Наиболее интенсивные полосы во всех спектрах регистрируются в области 1208 и $1152 \mathrm{~cm}^{-1}$ (валентные колебания связи C-F групп $\mathrm{CF}_{2}$ ). В спектре теломера ТФЭ во фреоне (спектр 1a) полосы поглощения фрагментов молекулы $\mathrm{C}_{2} \mathrm{~F}_{3} \mathrm{Cl}_{3}$ имеют малую 

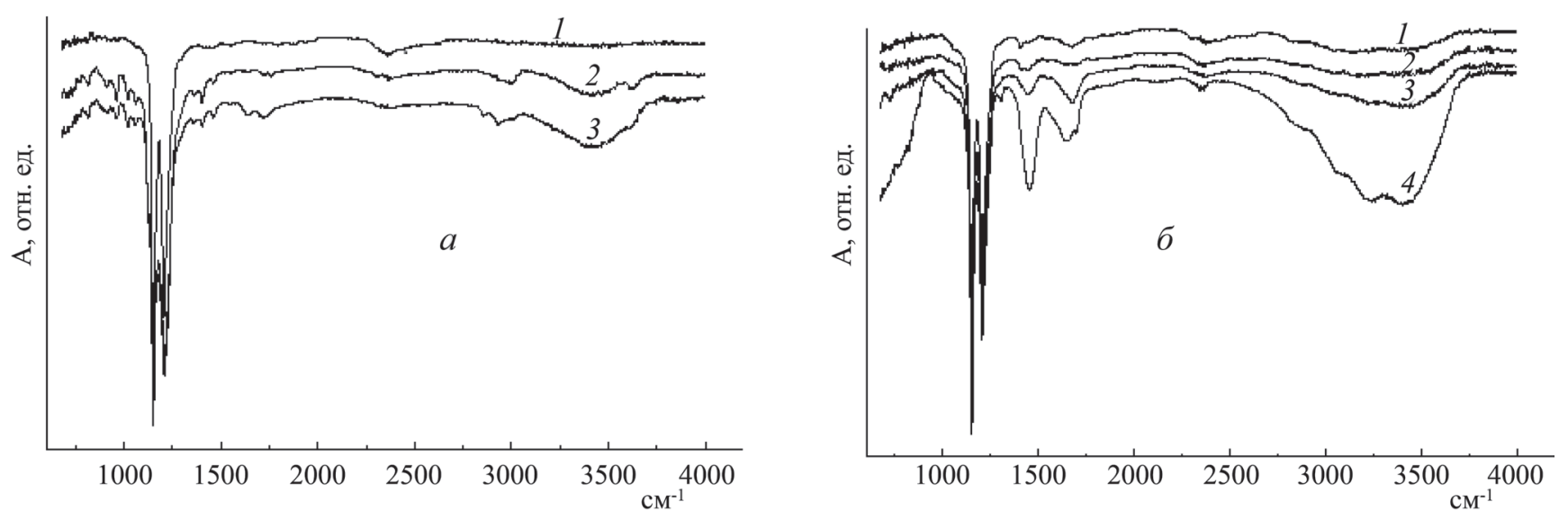

Рис. 2. ИК-спектры поглощения теломеров ТФЭ, полученных в различных телогенах

(а) фреон 113 (1), фреон 113 + этанол с концентрацией $\mathrm{C}_{2} \mathrm{H}_{5} \mathrm{OH} 0,92$ (2); 1,74 (3) моль/л. (б) фреон $113+$ аммиак с концентрацией $\mathrm{NH}_{3} 0,06$ (1); 0,18 (2); 0,28 (3); 0,46 моль/л (4)

интенсивность, регистрируются вместе с полосами валентных колебаний C-F, поскольку велика длина цепи и, соответственно, мало концевых групп. В спектрах теломеров, полученных в смеси телогенов, появляются дополнительные полосы концевых групп. При добавлении этанола (рис. 2a) наблюдается ряд полос в области 700-1000, 1300-1700 и 2900-3600 см с $^{-1}$ связанных с колебаниями фрагментов молекул фреона и спирта, являющихся концевыми группами. Очевидно также, что относительная интенсивность этих полос (как фреоновых, так и спиртовых) возрастает с увеличением концентрации спирта в смеси растворителей (спектры $2 a$, $3 a)$, что подтверждает вывод об уменышении длины цепи теломера. Наиболее характерные полосы поглощения, связанные с наличием спиртовых концевых групп, регистрируются в области $1400 \mathrm{~cm}^{-1}$ (деформационные С-H), 2800-3000 см-1 (валентные $\mathrm{C}-\mathrm{H})$ и $3400 \mathrm{~cm}^{-1}$ (колебания гидроксильной группы $\mathrm{OH})$. Аналогичная картина наблюдается при введении аммиака в реакционную смесь. Образуются теломеры, в состав которых, помимо фреоновых, входят аминогруппы, о чем свидетельствует появление характерных полос поглощения. Валентные колебания связи N-H аминогруппы наблюдаются

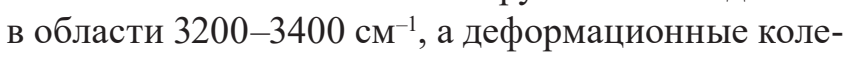
бания регистрируются при $\sim 1650 \mathrm{~cm}^{-1}$. Высокая относительная интенсивность полос поглощения связей N-H (рис. 2б) по сравнению с интенсивностью полос C-F (1100-1200 cм-1) позволяет сделать вывод о большом количестве концевых аминогрупп, т.е. об относительно малой длине цепи образующихся теломеров. По результатам элементного анализа на содержание хлора и азота длина цепи теломеров с ОН- концевой группой составляет 10-15 звеньев ТФЭ, а с $\mathrm{NH}_{2}$-группой $\mathrm{n} \sim 20-40$ в зависимо- сти от концентрации этанола ли аммиака во фреоне 113.

Для получения теломеров с силановыми группами в качестве телогена использован триметилхлорсилан ( $\left.\mathrm{C}_{3} \mathrm{H}_{9} \mathrm{ClSi}, \mathrm{TMXC}\right)$. Выбор силана был обусловлен тем, что фторкремнийорганические соединения активно используются для создания гидрофобных и супергидрофобных покрытий на различные материалы [34-36]. Такие покрытия обладают уникальными характеристиками - водонепроницаемостью, устойчивостью к биообрастанию и неорганическим загрязнениям, стойкостью к коррозии, способностью к самоочищению, а также антиобледенительными свойствами, что важно при использовании модифицированных материалов в жестких климатических условиях Арктики. Длина цепи теломеров в ТМХС по данным элементного анализа на содержание хлора $\sim 20$ и 30 звеньев в зависимости от концентрации ТФЭ. ИКспектры поглощения аналогичны, представленным на рис. 2, но дополнительные полосы регистрируются в областях 760, 850, 1250, 2900-3000 см характерных для силанов, содержащих метильные группы. Помимо этого, наблюдается полоса $812 \mathrm{~cm}^{-1}$, относящаяся к колебаниям связи $\mathrm{C}-\mathrm{Cl}$, поскольку одной из концевых групп полученного теломера является $\mathrm{Cl}$.

Все описанные теломеры представляют собой коллоидные растворы, их вязкость определяется исходной концентрацией ТФЭ и телогеном, в котором проводился синтез. Они разбавляются растворителем до концентрации, необходимой при практическом применении. Таким образом, резюмируя сказанное выше, для гидрофобизации стеклотканей и высокопористых керамических материалов был получен ряд теломеров с длиной 
цепи от 10 до 100 звеньев ТФЭ и большим набором концевых групп, в том числе химически активных (гидроксильные, силановые, аминогруппы). Далее будут приведены основные результаты по использованию полученных теломеров для гидрофобизации стеклотканей и пористых керамических материалов.

\section{Гидрофобизация алюмоборосиликатных стеклотканей и кремнеземных тканей}

Фторопластовые лакоткани, в которых в качестве основы используется стеклоткань, а в качестве пропиточной среды - суспензии фторопластов, широко востребованы, поскольку имеют ряд преимуществ (более высокая морозо- и теплостойкость, лучшие диэлектрические свойства, стойкость к агрессивным компонентам, хорошие антифрикционные и гидрофобные свойства) перед аналогами. Это достаточно энергоемкая затратная технология, включающая операции горячего прессования и введения значительных масс фторопласта до 50-80\%. Альтернативой фторопластам могут служить растворы теломеров ТФЭ. Жидкофазное состояние позволяет при их применении использовать традиционные технологии, в частности, наносить теломеры на стеклоткань или кремнеземную ткань методом пропитки или пульверизации.

В качестве образцов стеклоткани использовали стандартную алюмоборосиликатную стеклоткань с простейшим тканым переплетением (размер волокон и межволоконных полостей стеклоткани составляет 6-9 мкм), размером $5 \times 5$ см. Было показано, что для придания алюмоборосиликатным стеклотканям высокой гидрофобности необходима их предварительная обработка от технического замасливателя и активация поверхности. Оптимальным способом обработки является прогрев при $450-470{ }^{\circ} \mathrm{C}$ для удаления технического замасливателя и активация поверхности раствором соляной кислоты в течение 20 мин. В результате химической активации ткани методом кислотного травления происходит формирование поверхностного микрорельефа волокна и образование химически активных силанольных групп, которые улучшают связь теломера с поверхностью. Наличие силанольных групп подтверждено анализом ИК-спектров активированной ткани. Нанесение растворов теломеров на образцы стеклоткани проводилось методом пропитки. Обработка образцов включала следующие операции: погружение образца в раствор теломера (30-40 сек), сушка при $40{ }^{\circ} \mathrm{C}$ (40 мин) и прогрев при $150{ }^{\circ} \mathrm{C}(20$ мин). Количество теломера, нанесенного на обра- зец, контролировали гравиметрически. Концентрация пропиточных растворов составляла $\sim 3,0$ 4,0 масс. $\%$.

На первом этапе исследований были использованы теломеры ТФЭ в ацетоне, ЭА, ХБ, ПФХБ и фреоне 113 , имеющие различную длину цепи [9, 10]. Было показано, что пропитка алюмоборосиликатной стеклоткани растворами теломеров ТФЭ позволяет получить фторсодержащий стеклополимерный материал, который содержит несколько (4-6 \%) процентов фторполимера, но при этом обладает высокой гидрофобностью, термостойкостью, устойчивостью к воздействию агрессивных сред (щелочи, кислоты). Совокупность полученных экспериментальных результатов позволила сделать некоторые выводы о целесообразности использования различных теломеров для модифицирования стеклоткани. Оказалось, что теломеры ТФЭ во фреоне 113, имеющие длину цепи $\sim 100$ звеньев не позволяют получать хорошие однородные, сплошные покрытия и не могут быть рекомендованы для этих целей. Все остальные рассмотренные теломеры, имеющие длину цепи не более 50 звеньев, синтезированные в ацетоне, ПФХБ, ХБ и ЭА, технологически применимы для модификации стеклотканого наполнителя, обеспечивая изделию высокую гидрофобность при малом содержании (всего несколько процентов от массы ткани) нанесенного теломера. Наличие фторполимерного покрытия, обеспечивающего гидрофобность стеклоткани, подтверждено анализом ИК-спектров.

В спектре, помимо полос поглощения стеклоткани, появляются полосы поглощения (отмечены стрелками), связанные с наличием покрытия

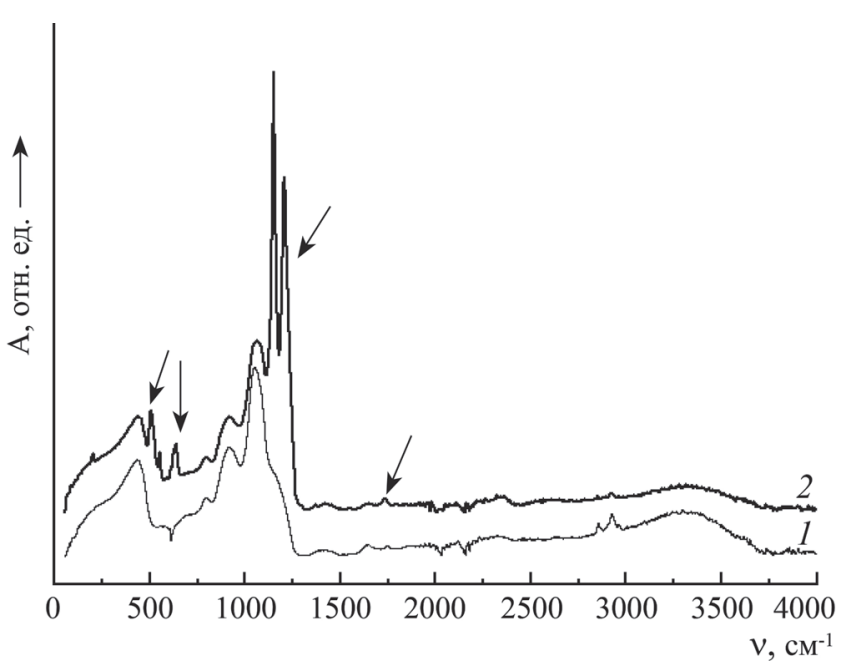

Рис. 3. ИК-спектры поглощения исходного образца стеклоткани (l) и обработанного раствором теломеров в ацетоне (2) 
из теломера. Наиболее интенсивные полосы регистрируются в области 1152 и 1208 см$^{-1}$. Они относятся к валентным колебаниям $v_{\mathrm{C}-\mathrm{F}}$ групп $\mathrm{CF}_{2}$ тетрафторэтиленовой цепи теломера. Помимо этих полос в спектре наблюдается ряд полос поглощения групп $\mathrm{CF}_{2}$ в области 500-750 $\mathrm{cm}^{-1}$ и полоса в $\sim 1720 \mathrm{~cm}^{-1}$, относящаяся к валентным колебаниям $\left(v_{\mathrm{C}=\mathrm{O}}\right)$ карбонильной группы ацетона, входящего в теломер в качестве концевой группы

Следует принимать во внимание температурный режим, при котором будут использоваться модифицированные теломером стеклоткани. Так, например, теломеры в ЭА не обладают высокой термостойкостью, но, с другой стороны, они более экологичны, чем теломеры, синтезированные в ПФХБ и ацетоне. Стеклоткань, гидрофобизированная раствором теломеров ТФЭ в ацетоне, ПФХБ может применяться при температуре до $400{ }^{\circ} \mathrm{C}$ практически без потери качества покрытия. При более высоких температурах (до $700-800{ }^{\circ} \mathrm{C}$ ) целесообразно использовать более термостойкие материалы (например, кремнезёмные стеклоткани с температурой размягчения $\sim 1000^{\circ} \mathrm{C}$ ).

Были проведены исследования по гидрофобизации кремнеземной ткани КТ-11-13 с использованием теломеров ТФЭ в ацетоне и ПФХБ [14]. Получен гидрофобный материал и показано, что для гидрофобизации КТ-11-13 требуется предварительная обработка ткани от технического замасливателя и нанесение большего количества теломеров (5-8 \%), что связано с плотностью плетения ткани. Сравнение гидрофобных свойств образцов, полученных с применением теломеров в ацетоне и ПФХБ показало, что использование теломеров ТФЭ в ПФХБ не дает ощутимых преимуществ, поэтому вполне достаточно использовать теломеры в ацетоне, синтез которых более дешев и экологичен.

На втором этапе исследований для гидрофобизации был выбран ряд теломеров с активными концевыми (OH, $\mathrm{NH}_{2}$, силановые) группами, которые могут улучшать связь теломера с подложкой.
Было показано, что радиационно-синтезированные теломеры ТФЭ в ТМХС, имеющие длину цепи $n \sim 20$ и активные силановые концевые группы, эффективны для гидрофобизации стеклоткани. Так, для достижения сравнимого уровня гидрофобности при использовании теломеров в ацетоне и этилацетате требуется 5-ти кратная пропитка, в хлористом бутиле и пентафторхлорбензоле - трех- и двукратная, соответственно. Теломеры ТФЭ в ТМХС позволяют получить материал с высокой степенью гидрофобности при однократной пропитке раствором теломера и минимальном содержании теломера $\sim 3 \%$. Это связано со свойствами теломеров, полученных в хлорсилане, а именно, с наличием силановых концевых групп, обеспечивающих лучшую адгезию теломера к подложке. Применение теломеров с гидроксильными и аминогруппами показало, что предпочтительно использование теломеров с $\mathrm{NH}_{2}$-группами, поскольку они имеют оптимальную длину цепи (20-30 звеньев), более термостабильны, позволяют получить качественное однородное покрытие. Это заключение подтверждается измерением краевых углов смачивания $(\Theta)$ (рис. 4). Максимальные углы наблюдаются для образцов, обработанных теломерами с концевыми $\mathrm{NH}_{2}$-группами $\left(143^{\circ}\right)$, эти образцы близки к супергидрофобным. Минимальные краевые углы наблюдаются для образцов с покрытием из теломеров ТФЭ с гидроксильными концевыми гуппами $\left(114^{\circ}\right)$. В данном случае, вероятно, наличие концевых гидроксильных групп в теломере приводит к уменьшению краевых углов смачивания. Образцы, обработанные теломерами, синтезированными в ацетоне, занимают промежуточное положение. Краевые углы смачивания для образцов с покрытием из теломеров в ацетоне составляют $138^{\circ}$.

Таким образом, анализируя результаты, полученные при использовании теломеров, можно сделать выводы, что получен гидрофобный материал с содержанием фторполимера не более 5-10\%. Для получения качественного гидрофобного покрытия стеклоткани можно эффективно исполь-

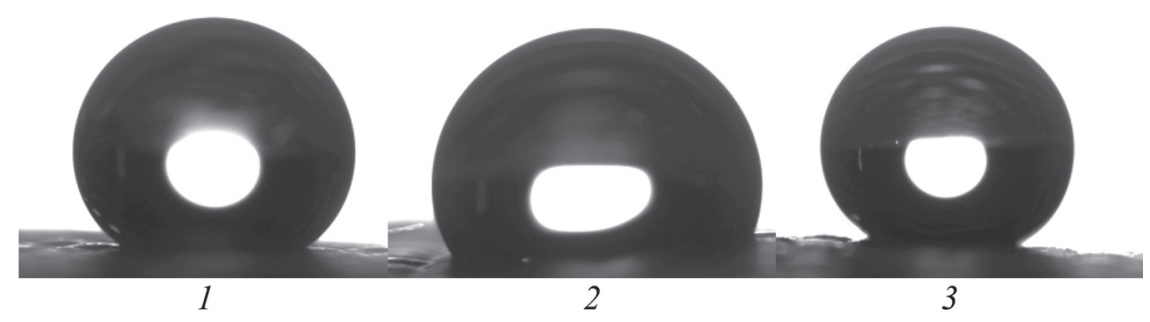

Рис. 4. Краевые углы смачивания образцов, обработанных теломерами ТФЭ в ацетоне (1), фреоне $113+$ этанол (2), фреоне $113+$ аммиак (3) 
зовать теломеры ТФЭ, полученные в ряде растворителей, имеющие длину цепи не менее 15-20 и не более 50 звеньев ТФЭ. Целесообразно использовать теломеры с химически активными силановыми и аминогруппами. При выборе теломера необходимо учитывать конкретные условия эксплуатации полученного материала.

\section{Гидрофобизация высокопористых керамических материалов на основе кварцевых волокон}

Как отмечено во введении, высокопористые теплозащитные материалы широко используются, в том числе, в экстремальных климатических условиях. Задача их гидрофобизации весьма актуальна. В работе использовали образцы материала марки ТЗМК-10 в виде брусков $5 \times 5 \times 10$ мм и волокнистый материал ТКВ с содержанием $\mathrm{SiO}_{2}$ до 99,9 \%, средний диаметр волокна 0,7-2,1 мкм.

Нанесение растворов теломеров проводилось методом пропитки. Концентрация пропиточных растворов составляла 1,5-3 масс.\%. Обработка образцов включала следующие операции: погружение образца в раствор теломера (0,5 час.), сушка при 50-60 ${ }^{\circ} \mathrm{C}$ (2-3 часа) и прогрев при $150{ }^{\circ} \mathrm{C}$ (0,5 час). Количество теломера, нанесенного на образец, контролировали гравиметрически.

При выборе теломеров мы учли результаты, полученные при гидрофобизации стеклоткани и кремнеземной ткани, где было показано, что для этих целей применимы теломеры с длиной цепи от 15-20 до 50 звеньев ТФЭ. Исходя из этого, на первом этапе выполнения работы для гидрофо- бизации были использованы теломеры ТФЭ с разной длиной цепи, синтезированные в ацетоне (n 15-20), хлористом бутиле (n 10-15) и пентафторхлорбензоле (n 50), позволившие получить хорошие покрытия на стеклоткани. Результаты экспериментов по пропитке ТЗМК-10 приведены в таблице 1. В таблице не приведены результаты по применению длинноцепочечных теломеров ТФЭ в ПФХБ, поскольку оказалось, что привес образцов минимален, не более 1 \%. Это свидетельствует о том, что в отличие от стеклотканей, они не проникают в поры ТЗМК-10, покрывают лишь внешнюю поверхность и не позволяют получить гидрофобный материал. Теломеры ТФЭ/ХБ позволили получить гидрофобный материал, но следует отметить, что привес образца существенно уменьшается при прогреве до $150{ }^{\circ} \mathrm{C}$, что ограничивает температурный интервал применения полученного материала. Теломеры в ацетоне позволяют получить гидрофобный материал, причем независимо от концентрации пропиточного раствора. Прогрев при $150{ }^{\circ} \mathrm{C}$ приводит к потере всего 3-5 \% массы теломера. О гидрофобности обработанного теломерами в ацетоне образца ТЗМК-10 можно судить по измерениям краевых углов смачивания, которые составляют $139,5^{\circ}$. Таким образом, выбирая из этих трех теломеров, следует отдать предпочтение теломерам ТФЭ, полученным в ацетоне.

По аналогии со стеклотканями, для гидрофобизации ТЗМК-10 были также выбраны теломеры с химически активными концевыми ОН-, $\mathrm{NH}_{2}-$ и силановыми группами, синтезированные в бинарных растворителях фреон 113 + этанол, фреон 113 + аммиак и ТМХС. Результаты этих опы-

Привес образцов ТЗМК-10, обработанных различными теломерами ТФЭ

Таблица 1

\begin{tabular}{|c|c|c|c|c|}
\hline Состав теломера & $\mathrm{C}_{\mathrm{p}-\mathrm{pa}}$, мacc.\% & Кратность пропиток & Привес, \% & $\Theta^{\circ}$ \\
\hline \multirow[t]{2}{*}{ ТФЭ/ацетон } & 1,6 & 1 & 5,7 & 139,5 \\
\hline & & 2 & 8,8 & \\
\hline \multirow[t]{2}{*}{ ТФЭ/ацетон } & 3,0 & 1 & 12,6 & \\
\hline & & 2 & 10 & \\
\hline \multirow[t]{2}{*}{ ТФЭ/ХБ } & 3,0 & 1 & 17 & \\
\hline & & & 8,1 & \\
\hline \multirow[t]{2}{*}{ ТФЭ/фреон 113 + этанол } & 3,0 & 1 & 7,4 & 106,8 \\
\hline & & 2 & 6,8 & \\
\hline \multirow[t]{2}{*}{ ТФЭ/фреон $113+\mathrm{NH}_{3}$} & 3,0 & 1 & 7,1 & 140,1 \\
\hline & & 2 & 8,5 & \\
\hline \multirow[t]{4}{*}{ ТФЭ/ТХМС } & 1,5 & 1 & 2,2 & 101,5 \\
\hline & & 2 & 2,0 & \\
\hline & & 3 & 1,7 & \\
\hline & & 4 & 0,9 & \\
\hline
\end{tabular}


тов приведены в таблице 1. Суммарный привес образцов ТЗМК-10 после двух пропиток и прогрева при $150{ }^{\circ} \mathrm{C}$ для теломеров с ОН- и $\mathrm{NH}_{2}$-группами составляет 14,2 и 15,6 \%. Общий привес образцов, модифицированных теломерами с силановыми концевыми группами, после 4-х пропиток составил $6,8 \%$. Одной из причин такого малого привеса является использование разбавленного раствора. Гидрофобные свойства поверхности модифицированного материала были оценены экспрессметодом, заключающемся в определении времени впитывания капли воды, нанесенной на поверхность образца. Образцы, обработанные всеми теломерами, гидрофобны, поскольку время впитывания капли превышает 60 мин., что соответствует критериям гидрофобного материала. Были измерены краевые углы смачивания для всех образцов, включая образцы, обработанные теломерами ТФЭ в ацетоне. Эти углы для образцов с гидрофобным покрытием из теломеров с ацетоновыми, $\mathrm{NH}_{2}, \mathrm{OH}$ и силановыми группами составляют 139,5, 140,1, 106,8 и $101,5^{\circ}$. Очевидно, что самые малые краевые углы смачивания получены для ТЗМК-10, обработанного теломерами, синтезированными в ТХМС и бинарном растворителе фреон 113 + этанол. Наличие концевых гидроксильных групп в теломере, приводит к уменьшению $\Theta$ при контакте поверхности ТЗМК-10 с водой. Не достаточно высокие значения краевых углов для теломеров ТФЭ с силановыми концевыми группами могут быть связаны с тем, что в составе таких теломеров возможно появление концевых гидроксильных групп при гидролизе связи $\mathrm{Si}-\mathrm{Cl}$ в процессе хранения теломера или пропитки образцов. Возможность гидролиза такой связи вполне очевидна и наличие $\mathrm{HCl}$ в исходном триметилхлорсилане легко обнаруживается индикаторной бумагой.

О наличии фторполимерного покрытия, обеспечивающего гидрофобность ТЗМК-10, свидетельствуют ИК-спектры поглощения. На рис. 5 приведен фрагмент спектра исходного ТЗМК-10 (1) и обработанного (2) теломерами ТФЭ с аминными концевыми группами.

Наиболее интенсивные полосы поглощения в спектре 1 наблюдаются в области $1100-1200 \mathrm{~cm}^{-1}$ (валентные колебания связи $\mathrm{Si}-\mathrm{O}$ ) и $470 \mathrm{~cm}^{-1}$ (деформационные колебания связи $\mathrm{Si}-\mathrm{O})$. В спектре гидрофобного образца появляются дополнительные полосы поглощения (отмечены стрелками) в области 1150 и $1200 \mathrm{~cm}^{-1}$, которые относятся к валентным колебаниям $v_{\mathrm{C}-\mathrm{F}}$ групп $\mathrm{CF}_{2}$ теломерной цепи.

Обработка образцов ТКВ проводилась с применением теломеров ТФЭ, синтезированных в ацетоне. Привес образцов ТКВ, обработанных теломерами и прогретых при $150{ }^{\circ} \mathrm{C}$ составляет 14 и $40 \%$

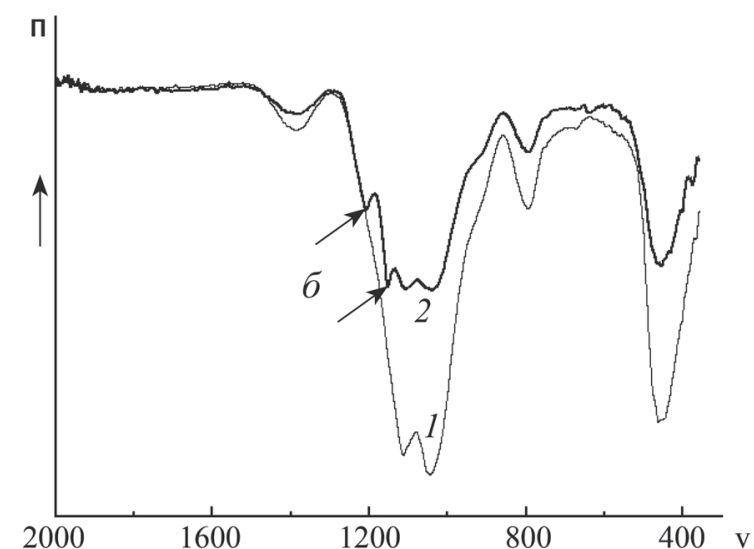

Рис. 5. ИК-спектры пропускания П исходного ТЗМК-10 (1) и обработанного теломерами ТФЭ (2). v - волновое число (см-1)

при концентрации раствора 1,6 и 3,0 масс.\%. Очевидно, что пропитку волокон следует проводить разбавленным раствором, поскольку нанесение слишком большого количества теломера не имеет никакого смысла, поскольку и при содержании теломера $14 \%$, образец ТКВ становится гидрофобным. Измерить краевые углы смачивания на ТКВ не представляется возможным.

Гидрофобность образцов ТКВ проверялась путем погружения образцов в воду. Гидрофобные образцы, обработанные теломерами $\left(\mathrm{C}_{\mathrm{p}-\mathrm{pa}} \sim 1,6\right.$ масс.\%), обладают длительной плавучестью в воде (отмечен стрелкой на рис. 6), в то время как необработанный исходный образец тонет в воде за несколько секунд. Наблюдения за образцом ТКВ проводились в течение нескольких суток.

Анализ полученных результатов позволяет сделать заключение, что теломеры синтезирован-

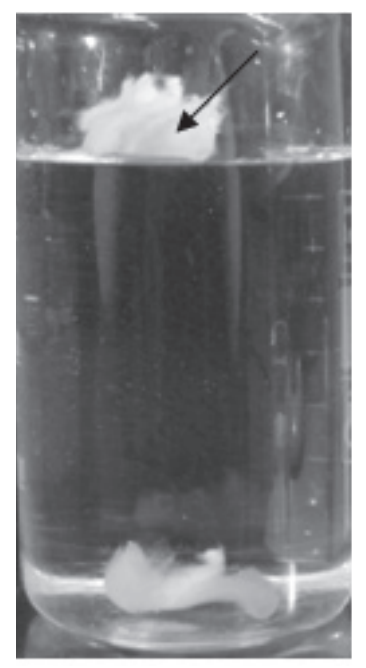

Рис. 6. Фото гидрофобного ТКВ в водной среде 
ные в ряде растворителей, имеющие разную длину цепи и различные концевые группы могут быть использованы для гидрофобизации высокопористых теплозащитных материалов на основе кварцевых волокон.

\section{Выводы}

1. Показана принципиальная возможность использования растворов ряда теломеров ТФЭ для гидрофобизации высокопористых теплозащитных керамических материалов на основе кварцевых волокон и стекло- и кремнеземных тканей.

2. Получены образцы высокогидрофобных материалов ТЗМК-10 и алюмоборосиликатных тканей, содержащих малое количество фторполимера и имеющих краевые углы смачивания $\sim 140^{\circ}$.

3. Наиболее перспективными для гидрофобизации являются теломеры ТФЭ, синтезированные в ацетоне и смеси растворителей фреон $113+$ аммиак.

4. Анализ ИК-спектров поглощения подтверждает наличие фторполимерных покрытий из теломеров ТФЭ, обеспечивающих высокую степень гидрофобности модифицированным материалам.

5. Полученные гидрофобные материалы (ТЗМК-10, ТКВ, кремнеземные и алюмоборосиликатные стеклоткани), обладая высокой гидрофобностью, устойчивостью к агрессивным средам, термостабильностью могут найти применение в экстремальных климатических условиях Арктики.

Работа выполнена по теме № 0089-2019-0008 Государственного задания, № гос.регистрациии AAAA-A19-119041090087-4, поддержке программы фундаментальных исследований президиума РАН КП 19-280 (П 22) «Перспективные физико-химические технологии спечиального назначения» и проекта РФФИ № 18-48-370005.

\section{Лumepamypa}

1. Кирюхин Д.П., Невельская Т.И., Ким И.П., Баркалов И.М. Высокомолек. соед. А. 1982. Т. 24. № 2. С. 307311.

2. Патент РФ 2381237. Б.И. №3. 2010. Фтортеломеры алкилкетонов, способы их получения (варианты) и способ получения функциональных покрытий на их основе.

3. Свидетельство на товарный знак (обслуживание) №351414. «ЧЕРФЛОН®», приоритет 05 марта 2007 г.

4. Кирюхин Д.П., Ким И.П., Бузник В.М., Игнатьева Л.Н., Курявый В.Г., Сахаров С.Г. Рос. хим. Ж. (Ж.
Pос. хим. об-ва им. Д.И. Менделеева). 2008. T. LII. №3. С. 66-72.

5. Кирюхин Д.П., Ким И.П., Бузник В.М. Химия высоких энергий. 2008. Т. 42. № 5. С. 393-400.

6. Кирюхин Д.П., Кичигина Г.А., Бузник В.М. Высокомолек. соед. 2013. Т. 55. № 11. С. 1321-1332.

7. Кирюхин Д.П., Кичигина Г.А., Куші П.П., Бузник В.М. Низкомолекулярные фторполимерные материалы. Монография “Фторполимерные материалы” / отв. ред. В.М. Бузник / (глава 4). - Томск: Изд-во НТЛ, 2017. $600 \mathrm{c}$.

8. Кирюхин Д.П., Кичигина Г.А., Аллаяров С.Р., Бадамшина Э.Р. Химия высоких энергий. 2019. Т. 53. №3. C. 224-234.

9. Алдошин С.М., Барелко В.В., Кирюхин Д. П., Кушч П.П., Петряков Д.Н., Дорохов В.Г., Быков Л.А. Доклады Академии наук. 2013. Т. 449. № 1. С. 55-59.

10. Кичигина Г.А., Кущи П.П., Кирюхин Д.П., Барелко В.В., Дорохов В.Г., Быков Л.А., Кузнецчов М.В. Химическая технология. 2015. Т. 16. № 6. С. 326-333.

11. Большаков А.И., Кичигина Г.А., Кирюхин Д.П. Химия высоких энергий. 2009. Т. 43. №6. С. 512-515.

12. Кичигина Г.А., Кущ П.П., Кирюхин Д.П. Химия высоких энергий. 2013. Т. 47. № 1. С. 34-37.

13. Кирюхин Д.П., Кичигина Г.А., Кущ П.П., Курявый В.Г., Бузник В.M. Известия АН. Серия химическая. 2013. № 7. С. 1659-1665

14. Кичигина Г.А., Куш П.П., Кривоногова Е.А., Кирюхин Д.П., Дорохов В.Г., Барелко В.В. Перспективные материалы. 2018. №2. С. 36-45.

15. Пророкова Н.П., Кумеева Т.Ю, Хореев А.В., Бузник В.М., Кирюхин Д.П., Большаков А.И., Кичигина Г.А. Химические волокна. 2010. №2 2. С. 25-30.

16. Пророкова Н.П., Бузник В.М., Кирюхин Д.П., Никитин Л.Н. Химические технологии. 2010. Т. 11. № 4. C. 213-223.

17. Пророкова Н.П., Кумеева Т.Ю., Кирюхин Д.П., Никитин Л.Н., Бузник В.М. Рос. хим. журн. (Журн. Рос. хим. об-ва им. Д.И. Менделеева). 2011. Т. 55. №3. C. 14-23.

18. Иванов В.К., Шапорев А.С., Кирюхин Д.П., Большаков А.И., Гиль Д.О., Кичигина Г.А., Козик В.В., Бузник В.М., Третьяков Ю.Д. Доклады Академии наук. 2010. T. 431. № 5. С. 630-633.

19. Кирюхин Д.П., Пророкова Н.П., Кумеева Т.Ю, Кичигина Г.А., Большаков А.И., Кущз П.П., Бузник В.М. Перспективные материалы. 2013. № 7. С. 73-79.

20. Бирюкова М.И., Юрков Г.Ю., Кирюхин Д.П., Ашмарин А.А., Кондрашов С.В. Перспективные материалы. 2014. № 5. С. 49-53.

21. Иванкин А.Н., Санаев В.Г., Горбачева Г.А., Агеев А.К., Кирюхин Д.П., Кичигина Г.А., Кущч П.П. Известия вузов. Лесной журнал 2018. №2. С. 122-132.

22. Gnedenkov S.V., Sinebryuhov S.L., Mashtalyar D.V., Nadaraia K.V., Kiryukhin D.P., Kichigina G.A., Kushch P.P., Buznik V.V. SURFACE \& COATINGS TECHNOLOGY. 2018. V. 346. P. 53-62.

23. Кичигина Г.А., Куш П.П., Кирюхин Д.П., Пророкова Н.П., Кумеева Т.Ю. Химия высоких энергий. 2020. T. 54. № 2. C. 135-141. 
24. Prorokova N.P., Kumeeva T.Yu., Kiryukhin D.P., Kichigina G.A., Kushch P.P. Progress in Organic Coatings. 2020. V. 139. 105485.

25. Патент РФ 2506224. Б.И. №4. 2014. Способ получения металл-полимерного композиционного материала для радиотехнической аппаратуры.

26. Патент РФ 2556111. Б.И. 2015. Способ получения антифрикционного материала.

27. Патент РФ 2577053. Б.И. № 7. 2016. Стеклополимерный композиционный материал и способ его изготовления.

28. Патент РФ 2586149. Б.И. № 16.2016. Способ получения слоистого пластика.

29. Патент РФ 2614917. Б.И. № 10. 2017. Способ получения защитных композиционных покрытий на сплаве магния.

30. Патент РФ 2666851. Способ изготовления гидрофобной, водостойкой облицовочной плит- ки из древесного материала. Дата публикации 2018.09.12.

31. Ивахненко Ю.А., Бабашов В.Г., Зимичев А.М., Тинякова Е.В. Авиац. материалы и технологии. 2012. № S. C. 380-385.

32. Щетанов Б.В., Ивахненко Ю.А., Бабашов В.Г. Рос. хим. журн. 2010. Т. 54. № 1. С. 12-19.

33. Китаева Н.С., Муханова Е.Е., Деев И.С. Тр. ВИАМ: Электрон. науч.-технич. журн. 2013. № 6. Ст. 03.

34. Кущ, П.П., Кичигина Г.А., Кирюхин Д.П., Баринов Д.Я. Химия высоких энергий. 2018. Т. 52. № 1 . C. $38-43$

35. Li X.-M., Reinhoudt D., Crego-Calama M. Chem. Soc. Rev. 2007. V. 36. P. 1350.

36. Бойнович Л.Б., Емельяненко А.М. Успехи химии. 2008. T. 77. № 7. C. 619-638.

37. Патент РФ 2400510. Б.И. № 27. 2006. Состав для получения супергидрофобного покрытия. 